\title{
SELEKSI BOBOT BADAN INDUK DAN EVALUASI KESULITAN PARTUS ANAK (Dystocia) SAPI BALI HASIL PERSILANGAN PEJANTAN SAPI LOKAL UNGGUL SULAWESI UTARA
}

\author{
Umar Paputungan*, Manopo Jouke Hendrik and Surtijono Edmundus Siswosubroto
}

Fakultas Peternakan, Universitas Sam Ratulangi, Manado, 95115

\begin{abstract}
ABSTRAK
Catatan kelahiran induk sebanyak 217 ekor bangsa sapi Bali disertai anak digunakan dalam kajian kesulitan partus anak (dystocia) induk remaja dan induk dewasa yang telah mengalami partus lebih dari satu kali melahirkan. Kesulitan partus anak diberi skor kesulitan partus dalam enam skor, diawali pada skor 0 menunjukkan partus normal sampai skor 5 menunjukkan partus tersulit yang membutuhkan pembedahan. Induk remaja dan induk dewasa serta anak merumput di tempat pasture rumput lokal sepanjang hari mulai jam 07.00 pagi sampai 17.30 sore tanpa tambahan pakan konsentrat sebagai cara pemeliharaan utama yang dilakukan oleh 104 pemilik ternak di wilayah pedesaan. Perbedaan kesulitan partus pada kedua kelompok induk remaja dan kelompok induk dewasa dianalisis dengan uji non parametrik "The Mann-Whitney U test", dengan memakai runutan data berbasis frekuensi kasus dalam skor kesulitan partus. Data skor kesulitan partus kedua kelompok induk remaja dan kelompok induk dewasa dirunut ke dalam runutan angka yang dimulai dari urutan angka terendah ke angka terbesar. Nilai $\mathrm{z}$ hitung dalam kajian ini yang menunjukkan frekuensi insiden kesulitan partus dalam kelompok induk remaja adalah lebih tinggi secara signifikan dibandingkan frekuensi insiden kesulitan partus dalam kelompok induk dewasa. Bobot hidup rendah
\end{abstract}

*Korespondensi (corresponding aouthor)

Email: umar_fapet@yahoo.com dan dimensi ukuran tubuh kelompok induk remaja cenderung tinggi mengalami insiden menderita kesulitan partus dibandingkan dengan kelompok induk dewasa sapi Bali. Seleksi induk remaja dengan dimensi tubuh dan bobot hidup yang relative berkembang baik terhadap bobot lahir anak yang diharapkan hendak direkomendasi untuk dapat mengurangi kesulitan partus.

Kata Kunci: Bangsa sapi Bali, ukuran tubuh induk dan anak, kesulitan partus.

\section{ABSTRACT}

BODY WEIGHT SELECTION
AND EVALUATION OF CALVING
DIFFICULTY (Dystocia) IN BALI
BREED FEMALE CATTLE MATED
WITH OUTSTANDING LOCAL
BULL OF NORTH SULAWESI.

Records on calving performances of 217 parental dams of Bali beef cattle breed including their calves were used to study calving difficulty of Bali beef cattle breed heifers and cows with experiencing in delivery of more than one generation of calving. The difficulties of calving were scored into calving difficulty scores of six scores, initiated at score 0 indicating normal calving to score 5 indicating the most difficult calving delivery requiring surgery. The parental heifers and adult cows as well as their calves grazed onto places within local grass pasture all days starting at 07.00 a.m. to 17.30 p.m. without supplementary feeds of concentrate as the main management system practiced by 104 farmers as the animal owners at rural areas. Differences of calving difficulties in both Bali beef cattle breed groups of heifers and cows were analyzed by 
nonparametric test of "The Mann-Whitney U test", using ranks of data based on the incidence frequencies of calving difficulty scores. Data of calving difficulty scores of both Bali beef cattle breed heifer group and cow group were ranked in to the numerical rank initiated from the lowest to largest numerical order. The calculated $\mathrm{z}$ value in this study indicating the incidence frequencies of calving difficulty in heifer group was significantly higher than those in cow group. Frequencies of calving difficulty on the category score basis in Bali beef cattle breed heifer group were significantly higher compared with those in Bali beef cattle breed cow group. Low live weights and body dimensions of heifer group highly tended to experience in the incidence and severity of calving difficulty compared with those of cow group. Selection of heifers with relatively well developed body dimensions and live weight relative to expected calf birth weight would be recommended to reduce calving difficulty.

Keywords: Bali beef cattle breed, dam and calf body measurements, calving difficulty.

\section{PENDAHULUAN}

Kelahiran (partus) pada sapi adalah proses keluarnya anak dari rahim (uterus) induknya setelah melewati masa bunting yang normal sekitar 275 sampai 285 hari (Ratnawati et al., 2007). Proses melahirkan bagi sapi betina merupakan bagian penting dari proses reproduksi yang dimulai dari perkawinan/inseminasi, kebuntingan dan akhirnya melahirkan anak. Tahapan-tahapan penting ini memberikan tanda-tanda khusus yang dapat diamati oleh para peternak sapi. Keberhasilan pemeliharaan sapi betina sangat ditentukan oleh baiknya proses reproduksi yang dilalui oleh sapi induk. Kerena sapi melahirkan satu kali dalam setahun/semusim maka kelahiran anak yang lancar tanpa mengalami kesulitan akan sangat menguntungkan peternak.

Kelahiran anak dari induk yang sehat tanpa mengalami kesulitan melahirkan akan juga berpengaruh terhadap perkembangan anak yang dilahirkan, dan terhadap induk sapi dalam rangka mempersiapkan diri menghadapi tahapan-tahapan reproduksi atau kebuntingan berikutnya. Selain faktor ternak sapi, faktor peternak juga harus berperan aktif dalam membantu kelancaran reproduksi ternaknya. Khusus menjelang sapi melahirkan anak, peternak harus rajin mengamati tanda-tanda sapi yang akan segera melahirkan, terutama pada kebuntingan tua.

Jika induk sapi tiba saat melahirkan anak, terlihat induk menjadi gelisah dan berjalan berputar-putar, sebentar tidur, sebentar berdiri, dan kadang-kadang mengeluarkan feses sedikit-sedikit. Selain itu, vulva kelihatan warna merah, bengkak dan keluar lendir. Terdapat tiga tahapan induk melahirkan normal yaitu pelebaran serviks (leher rahim) selama 2-6 jam, pengeluaran fetus 0.5-1 jam dan pengeluaran plasenta (selaput fetus) 4-5 jam (Hafez dan Hafez, 2000). Apabila proses kelahiran melebihi waktu 8 jam dari saat pertama kali seekor induk menunjukkan tanda untuk melahirkan dapat dikatakan sapi mengalami kesulitan melahirkan/partus anak atau dystokia, menyebabkan kematian anak dan atau induk (Meredith, 2000; Jackson, 2004). 
Kejadian dystokia pada ternak sapi diperkirakan sebesar 3,3\% dari populasi ternak, sehingga cukup menyebabkan kerugian petani yang berarti akibat kematian anak yang lahir (Manan, 2002). Tujuan penelitian ini adalah untuk mengidentifikasi faktor utama penyebab lama waktu dan kesulitan melahirkan/partus anak (dystocia) pada induk sapi Bali hasil perkawinan alam dan inseminasi buatan di Sulawesi Utara.

Komposisi bangsa ternak sapi lokal di Indonesia menunjukkan kisaran sapi Bali $33,73 \%$, sapi PO 23,88\%, sapi Madura $(5,16 \%)$, dan sapi lokal lain $(13,45 \%)$ (Data Dirjen Peternakan Kementan RI, 2017). Sapi Bali merupakan salah satu sapi potong lokal Indonesia yang memiliki kelebihan berupa kemampuan adaptasi yang tinggi terhadap lingkungan Indonesia baik terhadap iklim, ketersediaan pakan alami dan air, dan juga ketahanan terhadap bakteri maupun parasit.

Untuk pengembangan bibit unggul ternak sapi di Sulawesi Utara, Kabupaten Minahasa telah dijadikan sentra pengembangan bibit ternak sapi terutama sapi Bali dan sapi Peranakan Ongole (PO) melalui teknologi inseminasi buatan (IB). Pengembangan bibit unggul ternak sapi Bali Campuran (Bacan) melalui IB ini dipusatkan pada tiga kecamatan, yang terdiri dari kecamatan Kawangkoan, kecamatan Tompaso dan kecamatan Langowan untuk menunjang agribisnis peternakan sapi yang tersebar di Sulawesi Utara (Dinas Kehewanan Kabupaten Minahasa, 2017).

Permasalahan yang menjadi titik perhatian sekarang adalah masih lemahnya sistem pencatatan (recording system) variabel tentang ukuran morfometrik dan kondisi maternal induk sebagai dasar pelaksanaan seleksi. Saat ini penerapan teknologi IB hanya menitik-beratkan pada keberhasilan pencapaian pengembangan jumlah populasi ternak (kuantitas individu ternak) di wilayah daerah.

Pada periode tiga dasawarsa yang lalu, standar tinggi sapi Bali jantan dewasa dapat mencapai $135 \mathrm{~cm}$ dan betina $120 \mathrm{~cm}$, dengan berat badan rata-rata pada jantan mencapai lebih $450 \mathrm{~kg} / \mathrm{ekor}$ dan betina mencapai lebih 300 kg/ekor (DEPTAN RI, 1983). Sekarang ini, standar ukuran berat tubuh sapi Bali dewasa adalah rata-rata berada dibawah kisaran tersebut di atas, yaitu $289,14 \mathrm{~kg}$ /ekor betina dan sekitar 343,42 kg/ekor jantan (Paputungan dan Manopo, 2009). Penurunan bobot badan rata-rata populasi ternak yang terjadi dalam suatu wilayah bisa diakibatkan oleh peningkatan jumlah pemotongan dan pengeluaran/ ekspor ternak unggul tanpa diimbangi dengan proses seleksi dalam pengembang-biakan generasi anak (G1), sehingga terjadi proses yang disebut pengurasan genetik ternak (animal genetic degradation) yang tinggal menyisakan ternak tidak unggul seadanya 
untuk dikembang-biakkan (Udeh et al., 2011).

Seleksi berbasis performans $(S B P)$ perlu dilakukan untuk mempertahankan atau meningkatkan standar bobot badan dan ukuran morfometrik sapi Bali Lokal (Sutarno et al., 2005). Kendala yang masih menghambat teknologi IB di Sulawesi Utara adalah belum diimbangi proses seleksi terutama pemakaian induk betina unggul melalui SBP yang di IB, sehingga produktivitas individu generasi anak (G1) lambat mencapai performans sapi Bali yang unggul sesuai standar DEPTAN RI (1983). Bobot badan merupakan salah satu faktor yang penting dalam perkembangan ternak lokal, khususnya sapi potong (Lelana et al., 2003). Pengukuran morfometrik ternak memiliki ketelitian yang lebih baik untuk seleksi dibandingkan dengan pengukuran bobot badan (Ozkaya dan Bozkurt, 2009). Tujuan Penelitian adalah mengevaluasi efek langsung pelibatan induk generasi awal (G0) yang memiliki bobot badan rendah, sedang sampai tinggi terhadap bobot lahir anak dan kesulitan partus/melahirkan (dystocia) bagi generasi anaknya (G1) hasil persilangan, serta mengimplementasikan sistem seleksi berbasis performans $(S B P)$ sebagai indikator dalam proses seleksi ternak untuk upaya peningkatan kualitas reproduksi dan produksi secara genetik ternak sapi Bali Lokal dan upaya pencegahan kesulitan partus (dystocia).

\section{MATERI DAN METODE PENELITIAN}

\section{Koleksi Data}

Catatan proses kelahiran 217 induk sapi Bali termasuk anak sapi lahir di Sulawesi Utara digunakan dalam kajian kesulitan partus induk remaja dan induk dewasa (pernah melahirkan anak sebelumnya lebih dari satu kali). Catatan data panjang badan, lingkar dada dan bobot induk remaja, dewasa dan anak yang dilahirkan saat lahir digunakan dalam kajian ini. Rataan umur induk sapi Bali bervariasi dari tiga setengah sampai empat tahun induk remaja dan empat sampai lima tahun induk dewasa sesudah melahirkan yang terakumulasi lebih enam bulan (Januari-July 2019) di beberapa desa yang tersebar di Sulawesi Utara. Semua induk remaja dan dewasa dikandang ditempat lokasi sebagai miliki dari 104 petani. Induk remaja sebanyak 106 ekor dan induk dewasa sebanyak 111 ekor diukur panjang badan, lingkar dada dan bobot lahir dalamkurun 24 jam sesudah melahirkan anak termasuk ukuran anak sapi yang dilahirkan.

Pemantauan petani terhadap kesulitan partus pada induk remaja dan dewasa dapat memungkinkan menyeleksi anak lahir optimum milik induk remaja dan dewasa yang kemudian diidentifikasi catatan melahirkan normal dan abnormal. Kesulitan partus di beri skor kedalam skor kesulitan partus terdiri enam skor disesuaikan "Beef 
Improvement Federation (BIF) of the United

State of America (Lombard et al., 2003) pada level skor 0 sampai 5, yakni: Skor 0 menunjukkan partus normal, Skor 1 menunjukkan agak sulit partus tanpa bantuan, Skor 2 menunjukkan sulit partus dengan bantuan agak ringan, Skor 3 menunjukkan lebih sulit partus membutuhkan bantuan sederhana, Skor 4 menunjukkan lebih sulit partus membutuhkan bantuan intensif, dan Skor 5 menunjukkan tersulit partus membutuhkan operasi sesar. Skor 5 kesulitan partus yang membutuhkan operasi sesar tidak ditemukan dalam kajian ini. Deskripsi kejadian kesulitan partus dalam kajian ini terlihat seperti pada Gambar 1.

\section{Manajemen Ternak}

Petani memelihara sapi Bali secara tradisional menggunakan pakan rumput local di sekitar kebun kelapa dan areal rumput terbuka di sekitar areal pedesaan seperti diuraikan oleh Paputungan et al. (2016). Induk remaja dan dewasa serta anak sapi mereka merumput di areal padang rumput sepanjang hari mulai jam 07.00 pagi sampai jam 17.30 sore tanpa pakan tambahan konsentrat sebagai sistem manajemen yang dipraktekkan oleh 104 petani pemilik ternak di desa mereka masing-masing. Ternak kawin
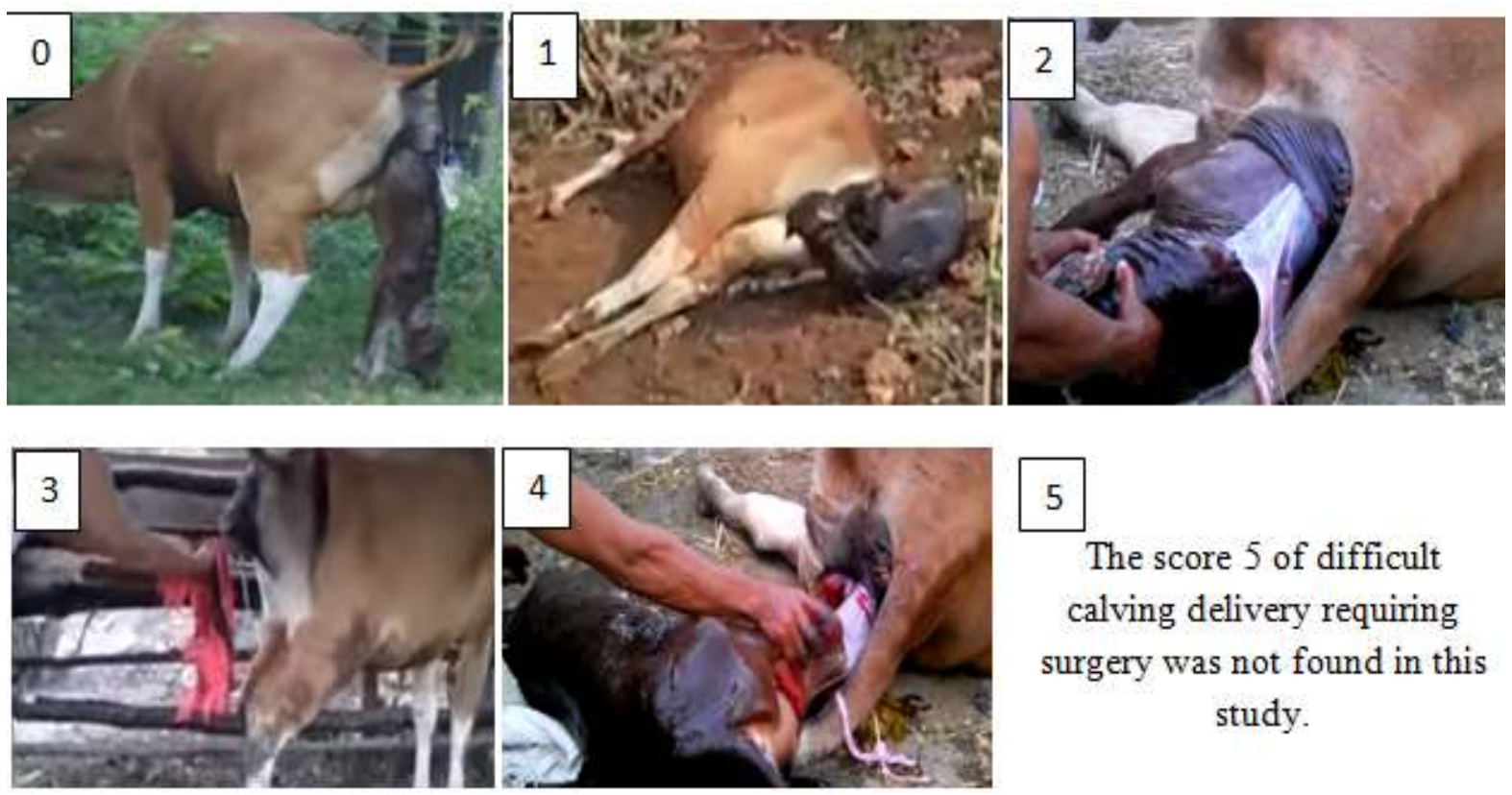

5

The score 5 of difficult calving delivery requiring surgery was not found in this study.

Foto deskripsi induk sapi Bali remaja dan dewasa dengan skor kesulitan partus 0, 1, 2, 3, 4 dan 5.

Gambar 1. Insiden kesulitan partus (Dystocia) induk sapi Bali yang dikawinkan dengan pejantan lokal unggul di pedesaan Sulawesi Utara. 
di padang rumput tempat ternak berada, sedangkan petani memonitor induk sapi milik mereka. Bila induk remaja dan dewasa menunjukkan tanda estrus, induk ini dikawinkan dengan pejantan local secara alami. Ternak diberi feed suplemen berupa "urea palm sugar block" pada sore harimenjelang malam (Paputungan et al., 2015).

Timbangan digital dipakai menimbang bobot ternak sebanyak 217 induk disaat ternak berdiri tetap sebagaimana diuraikan oleh Paputungan et al. (2000) dan Ozkaya dan Bozkurt (2009). Pada saat bersamaan, panjang badan dan lingkar dada diukur pula memakai "tape measure" pada induk remaja, dewasa dan anak dalam kurun waktu 24 jam sesudah lahir. Data pengukuran tubuh, bobot dan umur melalui pengaturan dianalisis memakai software sederhana dari fungsi program statistik dalam Excel XP 2007.

\section{Analisis statistik}

Perbedaan kesulitan partus pada kelompok induk sapi Bali remaja dan kelompok induk dewasa dilakukan analisis melalui uji nonparametrik (nonparametric test) dengan uji Mann-Whitney U (the MannWhitney $U$ test), memakai runutan data (data ranks) menurut Byrkit (1987) berdasarkan frekuensi insiden skor kesulitan partus. Data skor kesulitan partus dari dua kelompok induk sapi Bali remaja dan dewasa dirunut ke dalam runutan numerik (numerical rank) diawali dari urutan terendah ke urutan numerik terbesar. Jumlah runutan (rank sum) dari kelompok induk remaja didesain ke kelompok $\mathrm{R}_{1}$ dan jumlah runutan (rank sum) kelompok induk dewasa didesain ke kelompok $\mathrm{R}_{2}$ (Tabel 1). Perhitungan dua nilai dari uji statistic $\mathrm{U}$ (the statistical $U$ test) dalam setiap kelompok induk remaja $\left(U_{1}\right)$ dan kelompok induk dewasa $\left(\mathrm{U}_{2}\right)$ diterapkan memakai formulasi sesuai dalam Byrkit (1987), yakni:

$$
\begin{aligned}
& \mathrm{U}_{1}^{*}=\mathrm{n}_{1} \mathrm{n}_{2}+\frac{n 1(n 1+1)}{2}-\mathrm{R}_{1} \\
& \mathrm{U}_{2} *=\mathrm{n}_{1} \mathrm{n}_{2}+\frac{n 2(n 2+1)}{2}-\mathrm{R}_{2}
\end{aligned}
$$

Konsistensi formula di atas untuk $\mathrm{U}_{1} *+\mathrm{U}_{2} *$ harus sama dengan $\mathrm{n}_{1} \mathrm{n}_{2}$ dari kelompok induk remaja $\left(\mathrm{n}_{1}\right)$ dan kelompok induk dewasa $\left(\mathrm{n}_{2}\right)$ sebagaimana dinyatakan oleh Byrkit (1987). Distribusi sampel variabel U diprediksi menjadi normal dengan rataan $(\mu \mathrm{U})$ dan varians $\left(\sigma^{2} U\right)$ (Byrkit, 1987), dimana:

$$
\begin{aligned}
\mu \mathrm{U} & =+\frac{n 1 n 2}{2} \text { dan } \\
\sigma^{2} \mathrm{U} & =\frac{n 1 n 2(n 1+n 2+1)}{12} \text { or } \\
\sigma \mathrm{U} & =\sqrt{ } \frac{n 1 n 2(n 1+n 2+1)}{12}
\end{aligned}
$$

Uji statistic dari dua kelompok sampel ini memakai nilai z, dimana:

$$
\begin{aligned}
& \text { z calculated } *=\frac{U 1 *-\mu U)}{\sigma U} \text { or } \\
& z \text { calculated } *=\frac{U 2 *-\mu U)}{\sigma U}
\end{aligned}
$$

Nilai table z 0,05 adalah 1,645 dan nilai table z 0,01 adalah 2,323 (Byrkit, 1987). Jika nilai 
hitung $\mathrm{z}^{*}$ (z hitunf) lebih tinggi dari nilai table $\mathrm{z} \quad 0,05 \quad(1,645)$, maka hal ini menunjukkan bahwa frekuensi insiden kesulitan partus kelompok induk remaja lebih tinggi secara signifikan $(\mathrm{P}<0,05)$. Jika nilai hitung $\mathrm{z}^{*}$ (z hitunf) lebih tinggi dari nilai table $\mathrm{z} \quad 0,01 \quad(2,323)$, maka hal ini menunjukkan bahwa frekuensi insiden kesulitan partus kelompok induk remaja lebih tinggi secara sangat signifikan $(\mathrm{P}<0,01)$. Frekuensi kesulitan partus berdasarkan kategori skor dalam kelompok induk sapi Bali remaja lebih tinggi secara sangat signifikan $(\mathrm{P}<0,01)$ dibandingkan dengan kelompok induk sapi Bali dewasa. Jumlah induk remaja dan dewasa dengan skor kesulitan partus terlihat pada Tabel 1.

\section{HASIL DAN PEMBAHASAN}

Hasil yang dicapai yakni penelitian telah selesai dilaksanakan dan selesai disusun artikel yang akan diterbitkan pada jurnal nasional terakreditasi, dengan pembahasan sebagai berikut:

\section{Insiden kesulitan partus}

Umumnya, kelahiran normal kelompok induk remaja dan kelompok induk dewasa dalam kajian ini adalah 41,5 persen dari total kelahiran ternak (Tabel 1). Kelahiran normal skor kesulitan partus 0 paling banyak terjadi dalamkelompok induk dewasa dengan tersentase 64,9 persen, sedangkan skor 0 ini terjadi dalam kelompok induk remaja dengan persentase hanya 16,9 persen. Kelahiran dengan kesulitan partus skor 1 dan skor 2 menunjukkan 20,7 persen dari total kelahiran anak. Kelahiran anak dengan kesulitan partus skor 1 dalam kelompok induk dewasa adalah 29,7 persen dari total kelompok induk dewasa yang menunjukkan lebih tinggi insiden kesulitan partus dibandingkan kelahiran skor 1 dalam kelompok induk remaja yang mencapai 11,3 persen dari total kelahiran kelompok induk remaja.

Kelahiran anak sapi dengan kesulitan partusskor 2 menunjukkan 5,4 persen dari total kelahiran anak sapi. Kelahiran anak dengan kesulitan partus skor 2 dalam kelompok induk remaja adalah 36,8 persen dari total kelahiran anak dalam kelompok induk remaja yang menunjukkan tinggi insiden dibandingkan kelahiran anak skor sama pada kelompok induk dewasa yang mencapai hanya 5,4 persen dari total kelahiran anak dalam kelompok induk dewasa. Kelahiran dengan kesulitan partus skor 3 menunjukkan 9,7 persen dari total kelahiran anak sapi. Kelahiran anak dengan skor 3 ini dalam kelompok induk remaja adalah 19,8 persen dari total kelahiran kelompok induk remaja, yang menunjukkan lebih tinggi insiden kesulitan partus dibandingkan dengan kesulitan partus skor 3 dalam kelompok induk dewasa dengan 0 persen dari total kelahiran dalam kelompok induk dewasa. 
Tabel 1. Deskripsi skor kesulitan partus dan frekuensinya pada induk remaja dan dewasa sapi Bali dengan hasil analisis "Mann-Whitney U test"

\begin{tabular}{|c|c|c|c|c|c|c|c|c|c|c|}
\hline \multicolumn{3}{|c|}{$\begin{array}{c}\text { Kelompok Induk } \\
\text { Remaja }\end{array}$} & \multicolumn{3}{|c|}{$\begin{array}{c}\text { Kelompok Induk } \\
\text { Dewasa }\end{array}$} & \multirow{2}{*}{$\begin{array}{c}\text { \% kedua } \\
\text { kelom- } \\
\text { pok }\end{array}$} & \multirow{2}{*}{$\begin{array}{l}\text { Ru- } \\
\text { nutan }\end{array}$} & \multirow[t]{2}{*}{$\begin{array}{l}\text { Runutan } \\
\text { Umum }\end{array}$} & \multicolumn{2}{|c|}{ Jumlah Runutan } \\
\hline Score & $\mathrm{n}_{1}$ & $\%$ & Score & $\mathrm{n}_{2}$ & $\%$ & & & & $\begin{array}{c}\text { Induk } \\
\text { remaja }^{+} \\
\left(\mathrm{R}_{1}\right)\end{array}$ & $\begin{array}{c}\text { Induk } \\
\text { Dewasa }^{++} \\
\left(\mathrm{R}_{2}\right)\end{array}$ \\
\hline 0 & 18 & 16,9 & 0 & 72 & 64,9 & 41,5 & $1-90$ & 45,5 & 819 & 3.276 \\
\hline 1 & 12 & 11,3 & 1 & 33 & 29,7 & 20,7 & $91-135$ & 113 & 1.356 & 3.729 \\
\hline 2 & 39 & 36,8 & 2 & 6 & 5,4 & 20,7 & $136-180$ & 158 & 6.162 & 948 \\
\hline 3 & 21 & 19,8 & 3 & 0 & 0 & 9,7 & $181-201$ & 191 & 4.011 & 0 \\
\hline \multirow[t]{2}{*}{4} & 16 & 15,2 & 4 & 0 & 0 & 7,4 & $202-217$ & 209,5 & 3.352 & 0 \\
\hline & 106 & 100 & & 111 & 100 & 100 & & & 15.700 & 7.953 \\
\hline
\end{tabular}

\begin{tabular}{lll} 
Z hitung & \multicolumn{3}{c}{ Nilai Z tabel } \\
\cline { 2 - 3 } & 0.05 & 0.01 \\
\hline
\end{tabular}

$8.9 * *$

1.6 2.3

+) Diperoleh dari hasil perkalian nilai $\mathrm{n}_{1} \mathrm{x}$ nilai "common rank" di baris skor yang sama;

$++)$ Diperoleh dari hasil perkalian nilai $\mathrm{n}_{2} \mathrm{x}$ nilai "common rank" di baris skor yang sama.

**) Nilai " $z$ calculated"menunjukkan lebih tinggi dari nilai " $z$ table" pada $0.01(\mathrm{P}<0.01)$.

$\mathrm{n}_{1}=$ total induk remaja yang berada dalam semua ketegori skor kesulitan partus (106).

$\mathrm{n}_{2}=$ total induk dewasa yang berada dalam semua ketegori skor kesulitan partus (111).

$\mathrm{U}_{1} *=1.737 ; \mathrm{U}_{2} *=10.029 ; \mathrm{n}_{1}=106 ; \mathrm{n}_{2}=111$.

$\mathrm{U}_{1} *+\mathrm{U}_{2}^{*}=\mathrm{n}_{1} \mathrm{n}_{2}=11.766$ menunjukkan konsistensi nilai, dan mengindikasikan prosedur perhitungan yang benar (Byrkit, 1987).

Terakhir, kelahiran dengan kesulitan partus skor 4 menunjukkan 7,4 persen dari total kelahiran anak. Kelahiran dengan kesulitan partus skor 4 dalam kelompok induk remaja adalah 15,1 persen dari total induk dalam kelompok remaja, yang memperlihatkan lebih tinggi insiden kesulitan partus dibandingkan dengan kelahiran skor 4 kesulitan partus dalam kelompok induk dewasa dengan insiden 0 persen dari total kelahiran dalam kelompok induk dewasa (Tabel 1).

\section{Ukuran dan bobot tubuh induk dan anak kaitan kesulitan partus}

Rataan panjang badan, lingkar dada dan bobot induk remaja dan kelompok induk dewasa bersama anak mereka dengan skor kesulitan partus diuraikan dalam Tabel 2. Sifat-sifat ukuran tubuh induk remaja yang berada pada skor 2 kesulitan partus lebih rendah secara nyata dibandingkan dengan kelompok induk dewasa yang berada pada skor 2 kesulitan partus. Semua induk remaja yang berada pada skor 3 dan 4 kesulitan partus memiliki sifat lebih kecil 
ukuran panjang badan, lingkar dada dan bobot badan dibandingkan dengan sifatsifat tersebut dari induk remaja yang berada pada skor 0 kesulitan partus (normal tanpa bantuan), skor 1 (agak sulit partus tanpa bantuan) dan skor 2 (sulit partus dengan bantuan agak ringan).

Rataan panjang badan, lingkar dada dan bobot badan kelompok induk dewasa yang berada pada skor 2 kesulitan partus lebih kecil secara nyata dibandingkan dengan kejadian induk dewasa yang berada pada skor 0 dan 1 kesulitan partus. Sifat ukuran tubuh indukini mengindikasikan bahwa induk dewasa dengan ukuran tubuh dan bobot badan kecil cenderung lebih tinggi risiko kesulitan partus. Selanjutnya, rataan panjang badan, dan lingkar dada baik dari induk remaja atau kelompok induk dewasa memperlihatkan rataan sama dalam semua kategori skor kesulitan partus. Rataan bobot lahir anak lebih berat secara nyata dari induk remaja yang berada pada skor 2 kesulitan partus. Untuk itu, insiden kesulitan partus ini boleh disebabkan perbedaan sifat ukuran tubuh dan bobot hidup induk remaja dari pada sifat-sifat dari anak mereka.

Rasio dalam persentase antara sifat anak dan sifat-sifat induk remaja dan induk dewasa diuraikan dalam Tabel 3. Rasio (persen) antara lingkar dada dan bobot lahir anak dan sifat-sifat yang sama dari induk remaja dan induk dewasa yang berada dalam skor kesulitan partus 2 tersebut pada induk dewasa yang berada dalam skor 2 kesulitan partus. Selanjutnya, semua rasio antara sifat-sifat anak dan sifat-sifat induk remaja yang berada pada skor 3 dan skor 4 kesulitan partus memiliki rasio lebih tinggi dari sifat-sifat tersebut dari anak dan induk remaja dibandingkan rasio tersebut pada induk yang berada pada skor 0 , skor 1 dan skor 2 kesulitan partus. Dalam kasus lain dari skor kesulitan partus induk dewasa, nampak menunjukkan bahwa semua rasio antara sifat-sifat anak dan sifat induk dewasa yang berada dalam skor 2 kesulitan partus adalah lebih tinggi secara signifikan dibandingkan rasio panjang badan lingkar dada dan bobot hidup bagi induk yang berada dalam skor 0 (partus normal) dan skor 1 (agak sulit melahirkan tanpa bantuan). Secara umum, semua jumlah induk bersama kategori skor kesulitan partus dari kelompok induk remaja dan kelompok induk dewasa adalah menurun berbanding terbalik dengan skor kesulitan partus yang meningkat. Deskripsi individu induk remaja dan induk dewasa melalui skor kesulitan partus diuraikan dalam Gambar 2. Kelahiran anak normal dengan skor 0 kesulitan partus terjadi terbanyak dalam kelompok induk dewasa dengan persentase 64,9 persen, sedangkan skor 0 ini terjadi dalam kelompok induk remaja dengan 
Tabel 2. Rataan dan standar error ukuran tubuh dan bobot badan induk remaja, induk dewasa dan anak yang diukur sesudah kelahiran bersama skor kesulitan partus

\begin{tabular}{|c|c|c|c|c|c|}
\hline \multirow{2}{*}{$\begin{array}{l}\text { Induk dan } \\
\text { anak sapi Bali }\end{array}$} & \multirow{2}{*}{$\begin{array}{l}\text { Skor } \\
\text { kesulitan } \\
\text { partus }\end{array}$} & \multirow[t]{2}{*}{$\mathrm{n}$} & \multicolumn{3}{|c|}{ Ukuran tubuh induk remaja, dewasa dan anak } \\
\hline & & & $\begin{array}{l}\text { Panjang badan } \\
(\mathrm{cm})\end{array}$ & $\begin{array}{l}\text { Lingkar dada } \\
\text { (cm) }\end{array}$ & Bobot hidup (kg) \\
\hline \multirow[t]{6}{*}{ Induk remaja } & 0 & 18 & $130,6 \pm 1,6^{\mathrm{a}}$ & $181,8 \pm 2,1^{\mathrm{a}}$ & $345,2 \pm 11,4^{\mathrm{a}}$ \\
\hline & 1 & 12 & $125,4 \pm 2,9^{a}$ & $175,1 \pm 3,7^{\mathrm{a}}$ & $314,8 \pm 18,0^{\mathrm{a}}$ \\
\hline & 2 & 39 & $116,2 \pm 1,1^{\text {b y }}$ & $157,7 \pm 1,8$ b y & $237,2 \pm 7,2^{\text {b y }}$ \\
\hline & 3 & 21 & $110,0 \pm 1,5^{\mathrm{c}}$ & $147,5 \pm 1,8^{\mathrm{c}}$ & $197,1 \pm 6,5^{\mathrm{c}}$ \\
\hline & 4 & 16 & $105,6 \pm 2,8^{\mathrm{c}}$ & $142,2 \pm 3,4^{\mathrm{c}}$ & $180,9 \pm 11,4^{\mathrm{c}}$ \\
\hline & & 106 & & & \\
\hline \multirow[t]{4}{*}{ Induk dewasa } & 0 & 72 & $131,2 \pm 1,0^{\mathrm{a}}$ & $183,0 \pm 1,3^{\mathrm{a}}$ & $351,3 \pm 6,9^{a}$ \\
\hline & 1 & 33 & $128,9 \pm 1,6^{\mathrm{a}}$ & $179,1 \pm 2,2^{\mathrm{a}}$ & $333,8 \pm 10,8 \mathrm{a}$ \\
\hline & 2 & 6 & $121,3 \pm 2,3^{\mathrm{bz}}$ & $168,7 \pm 4,5^{\mathrm{bz}}$ & $279,7 \pm 17,7^{\mathrm{bz}}$ \\
\hline & & 111 & & & \\
\hline Anak induk & 0 & 18 & $54,3 \pm 0.2$ & $72,9 \pm 0.4$ & $26,1 \pm 0,3^{b c}$ \\
\hline \multirow{5}{*}{ remaja } & 1 & 12 & $54,6 \pm 0.2$ & $74,4 \pm 0.2$ & $27,0 \pm 0,2^{a}$ \\
\hline & 2 & 39 & $54,4 \pm 0.1$ & $72,9 \pm 0.2$ & $26,2 \pm 0,2^{b}$ \\
\hline & 3 & 21 & $54,4 \pm 0.2$ & $72,8 \pm 0.3$ & $26,1 \pm 0,3^{b c}$ \\
\hline & 4 & 16 & $54,6 \pm 0.2$ & $72,4 \pm 0.2$ & $25,9 \pm 0,2^{\mathrm{c}}$ \\
\hline & & 106 & & & \\
\hline Anak induk & 0 & 72 & $54,4 \pm 0,1$ & $72,8 \pm 0,2$ & $26,1 \pm 0,1^{b c}$ \\
\hline \multirow[t]{3}{*}{ dewasa } & 1 & 33 & $54,3 \pm 0,2$ & $72,6 \pm 0,3$ & $26,0 \pm 0,2^{\mathrm{c}}$ \\
\hline & 2 & 6 & $54,7 \pm 0,2$ & $73,0 \pm 0,6$ & $26,3 \pm 0,3^{b}$ \\
\hline & & 111 & & & \\
\hline
\end{tabular}

persentase 16,9 persen. Kejadian-kejadian kesulitan partus ini dapat konsisten dengan ukuran bobot dan dimensi tubuh tertinggi, baik pada induk dewasa ataupun induk remaja (Gambar 3a dan 3b) dan dengan rasio terendah dari sifat-sifat phenotype anak terhadap sifat-sifat phenotype induk remaja dan induk dewasa (Gambar 4a and $4 b)$.

Kelahiran anak dengan kesulitan partus skor 1 dan skor 2 menunjukkan kesamaan kasus 20,7 persen dari total kelahiran anak. Kelahiran dengan kesulitan partus skor 1 dalam kelompok induk dewasa adalah 29,7 persen dari total kelahiran dalam kelompok induk dewasa, yang memperlihatkan lebih tinggi

dibandingkan kelahiran dengan kesulitan partus skor 1 dalam kelompok induk remaja yang hanya mencapai $11,3 \%$ 
Tabel 3. Rataan dan standar error ratio antara sifat-sifat anak dan sifat-sifat dari induk remaja dan induk dewasa bersama skor kesulitan partus

\begin{tabular}{|c|c|c|c|c|c|}
\hline \multirow[t]{2}{*}{$\begin{array}{l}\text { Anak Induk } \\
\text { sapi Bali }\end{array}$} & \multirow{2}{*}{$\begin{array}{l}\text { Skor } \\
\text { kesulitan } \\
\text { partus }\end{array}$} & \multirow[t]{2}{*}{$\mathrm{N}$} & \multicolumn{3}{|c|}{$\begin{array}{l}\text { Ratio (\%) antara sifat anak dan sifat-sifat induk remaja } \\
\text { dan induk dewasa }\end{array}$} \\
\hline & & & Panjang badan & Lingkar dada & Bobot hidup \\
\hline Anak induk & 0 & 18 & $41,6^{\mathrm{a}}$ & $40,1^{\mathrm{a}}$ & $7,6^{\mathrm{a}}$ \\
\hline \multirow[t]{5}{*}{ remaja } & 1 & 12 & $43,5^{a}$ & $42,5^{\mathrm{a}}$ & $8,6^{\mathrm{a}}$ \\
\hline & 2 & 39 & $46,8^{\mathbf{b}}$ & $46,3^{\mathbf{b} y}$ & $11,0 b^{\mathbf{y}}$ \\
\hline & 3 & 21 & $49,5^{\mathrm{c}}$ & $49,4^{\mathbf{c}}$ & $13,2^{\mathrm{c}}$ \\
\hline & 4 & 16 & $51,7^{\mathrm{c}}$ & $50,9^{\mathrm{c}}$ & $14,3^{\mathrm{c}}$ \\
\hline & & 106 & & & \\
\hline Anak induk & 0 & 72 & $41,5^{\mathrm{a}}$ & $39,8^{\mathbf{a}}$ & $7,4^{\mathbf{a}}$ \\
\hline \multirow[t]{2}{*}{ dewasa } & 1 & 33 & $42,2^{a}$ & $40,6^{\mathrm{a}}$ & $7,8^{\mathbf{a}}$ \\
\hline & 2 & 6 & $45,1^{\mathbf{b}}$ & $43,3^{\mathbf{b} z}$ & $9,4^{\text {b y }}$ \\
\hline
\end{tabular}

${ }^{\text {abc }}$ Means in the same column of each heifer's calf and cow's calf without common letters are different at $\mathrm{p}<0.05$.

${ }^{\mathbf{y z}}$ Means in the same column of heifer's calf and cow's calf without common letters are different at $\mathrm{p}<0.05$.

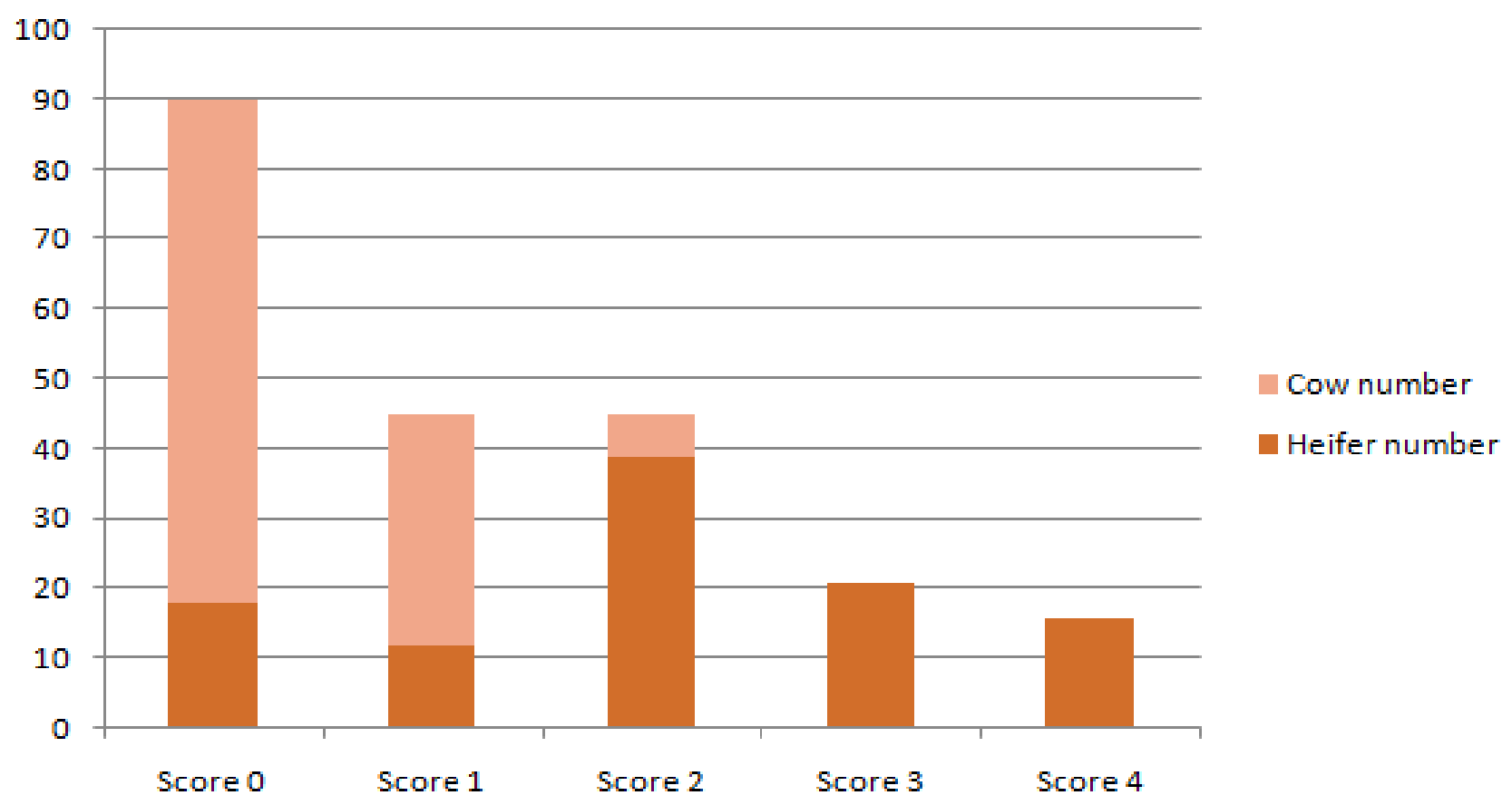

Gambar 2. Deskripsi jumlah individu induk remaja dan induk dewasa bersama skor kesulitan partus (Skor $0=$ partus normal to sampai skor $4=$ lebih sulit partus) 
dari total kelahiran dalam kelompok induk remaja. Namun kasus ini meningkat dalam kelompok induk remaja yang mencapai 36,8 persen berada pada kesulitan partus skor 2, sedangkan kasus ini berkurang dalam kelompok induk dewasa yang hanya mencapai 5,4 persen yang berada pada kesulitan partus skor 2. Peningkatan kasus kesulitan partus kelompok induk remaja dan kelompok induk dewasa (Gambar 2) berbanding terbalik dengan penurunan sifat-sifat phenotype dari induk remaja dan induk dewasa (Gambar 3a and 3b), tetapi konsisten mengikuti peningkatan rasio sifat-sifat phenotype anak terhadap sifatsifat phenotype induk remaja dan induk dewasa (Gambar 4a and 4b). Hendrik dan Paputungan (2016) melaporkan bahwa bobot lahir induk rendah $\left(\mathrm{G}_{0}\right)$ menghasilkan bobot badan keturunan generasi sampai ke 2 yang rendah pula $\left(\mathrm{G}_{2}\right)$ saat lahir dan saat umur 18 bulan dibandingkan dengan anak-anak generasi hasil keturunan induk berbobot lahir tinggi $\left(\mathrm{G}_{0}\right)$. Selanjutnya, kelas bobot lahir induk tinggi tidak mempengaruhi bobot sapihan dan bobot umur setahun pada generasi kedua (Hendrik dan Paputungan, 2016).

Biasanya induk-induk ini belum mencapai pertumbuhan penuh. Insiden dystocia yang tercatat dalam kajian ini adalah lebih tinggi dibandingkan insiden dystocia yang terdokumentasi sebelumnya oleh beberapa peneliti (Berry et al., 2007; Fiedlerova et al., 2008; Mee et al., 2008; Atashi et al., 2012a; Gürcan et al., 2014). Insiden kesulitan partus ini adalah sesuai dengan penelitian Atashi et al. (2012a) yang melaporkan bahwa induk remaja pertama partus lebih banyak memiliki kesulitan partus dibandingkan induk-induk yang lebih tua karena induk remaja belum pernah melahirkan sebelumnya dan Selanjutnya, kelahiran dengan kesulitan partus skor 3 menunjukkan 9,7 persen dari total kelahiran. Insiden kelahiran dengan kesulitan partus skor 3 kelompok induk remaja adalah 19,8 persen dari total kelahiran dalam kelompok induk remaja, yang memperlihatkan lebih tinggi insiden dibandingkan dengan kelahiran dengan kesulitan partus skor 3 dalam kelompok induk dewasa dengan 0 persen dari total induk dalam kelompok induk dewasa (Gambar 2). Insiden yang sama dari kelahiran terjadi dalam kelompok induk remaja dengan kesulitan partus skor 4, yang mencapai 15,1 persen, tanpa insiden kesulitan partus dalam kelompok induk dewasa (Gambar 2). 


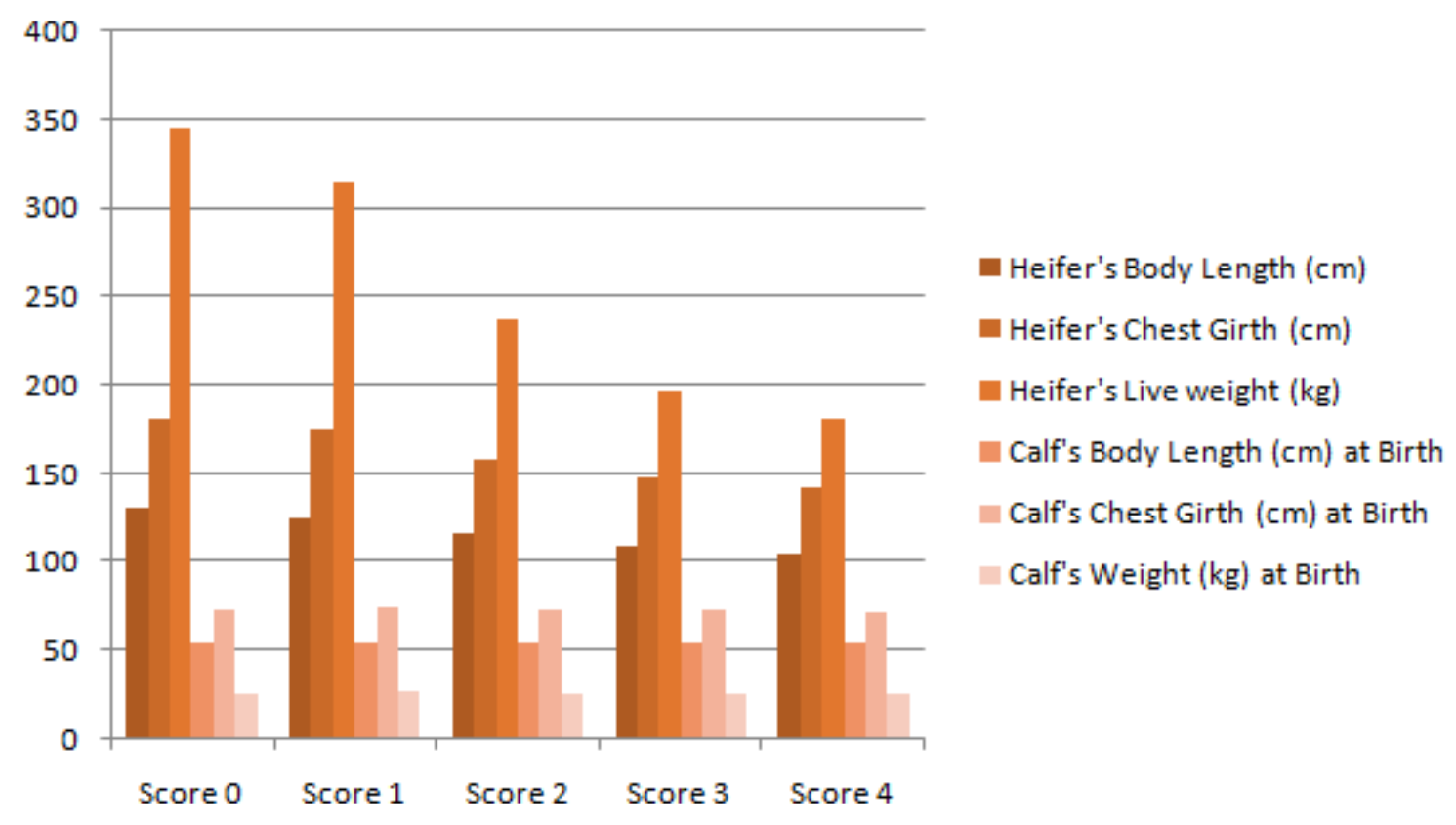

Gambar 3a. Sifat-sifat phenotipe induk remaja dan anak keturunan bersama skor kesulitan partus $(0=$ partus normal sampai $4=$ lebih sulit partus $)$

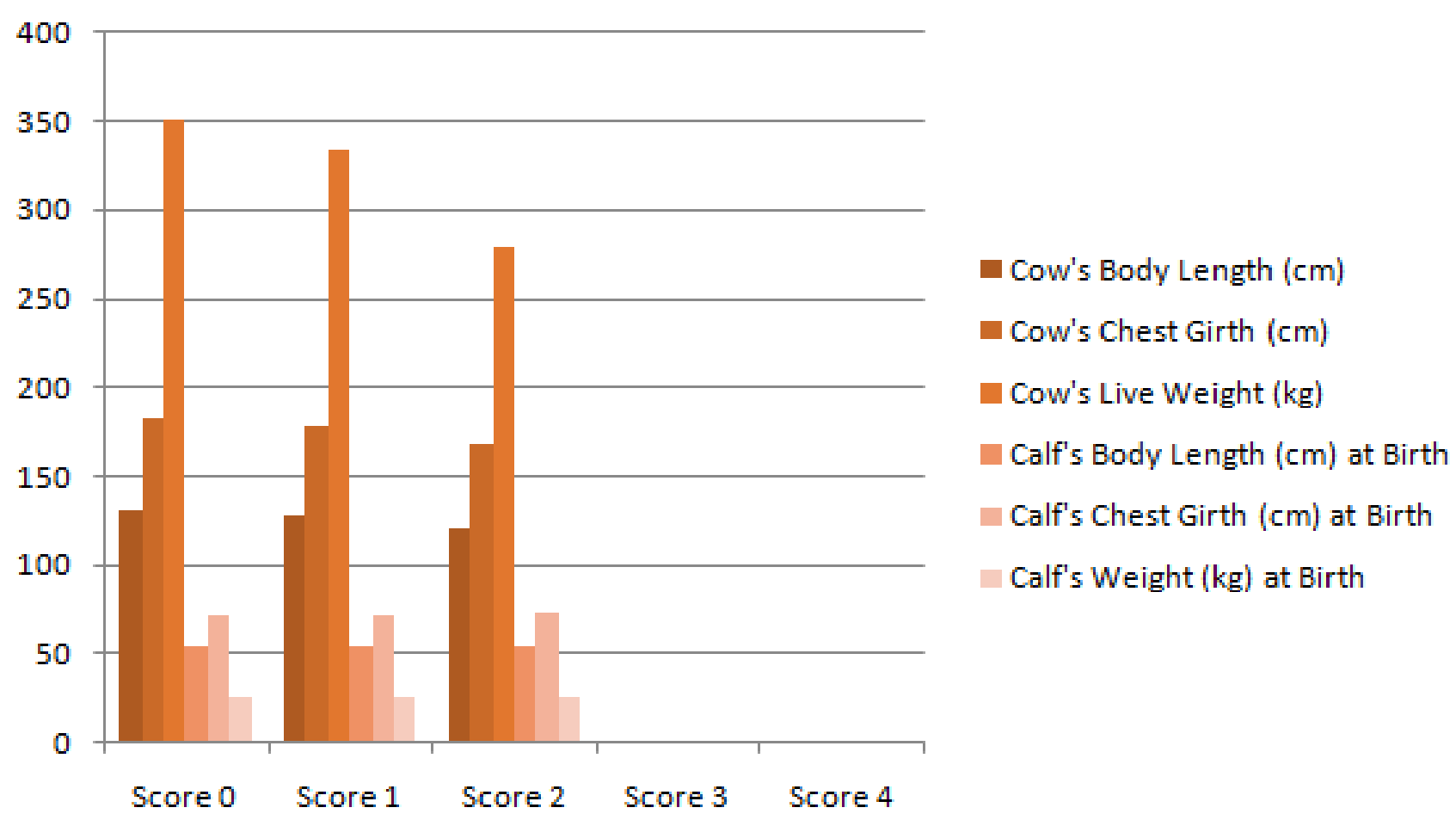

Figure 3b. Sifat-sifat phenotipe induk dewasa dan anak keturunan bersama skor kesulitan partus $(0=$ partus normal sampai $4=$ lebih sulit partus $)$ tanpa induk berada dalam kesulitan partus skor 3 dan 4 . 
Kasus kesulitan partus yang meningkat pada kelompok induk remaja dan induk dewasa berbanding terbalik dengan rendahnya sifat-sifat phenotype dari induk remaja dan induk dewasa (Gambar 3a and 3b), tetapi konsisten mengikuti peningkatan rasio sifatsifat phenotype anak terhadap sifat-sifat yang sama pada induk remaja dan induk dewasa (Gambar 4a and 4b). Bobot lahir induk yang lebih tinggi dapat dipakai sebagai induk pengganti yang potensial pada ternak sapi di Indonesia untuk perbaikan pertambahan bobot hidup ternak guna mencegah dan menghindari insiden kesulitan partus (Hendrik dan Paputungan, 2016).

Dalam kajian ini, bobot lahir anak jantan dan betina tidak berbeda secara signifikan yang menunjukkan kesamaan kontribusi anak jantan dan betina terhadap kesulitan partus, walaupun induk dewasa partus anak tunggal dengan capaian kemungkinan dystocia 19,6\% lebih tinggi dibandingkan induk dengan anak betina tunggal (Boujenane, 2017), yang melaporkan rataan skor dystocia 1,40 dan 1,33 pada masing-masing anak jantan dan betina. Hasil ini sesuai dengan asosiasi yang terdokumentasi sebelumnya antara kelamin anak dan dystocia (Johanson dan Berger, 2003; Berry et al., 2007; Atashi et al., 2012b). Insiden dystocia yang tinggi pada induk dewasa yang melahirkan anak jantan bisa dijelaskan oleh faktor anak jantan yang lebih tinggi dan besar saat lahir yang menyebabkan lebih banyak masalah dibandingkan anak betina. Kajian ini menunjukkan bahwa dimensi tubuh dan bobot hidup induk remaja dan induk dewasa berkontribusi terhadap variasi kesulitan partus sapi Bali yang telah sesuai dengan laporan-laporan lain (Johanson dan Berger, 2003; Berry et al., 2007). Kelompok induk remaja dan induk dewasa, ukuran dan bobot badan, bobot lahir anak dan rasio bobot anak dengan bobot induk memiliki efek signifikan terhadap performan melahirkan pada bangsa sapi Bali. 


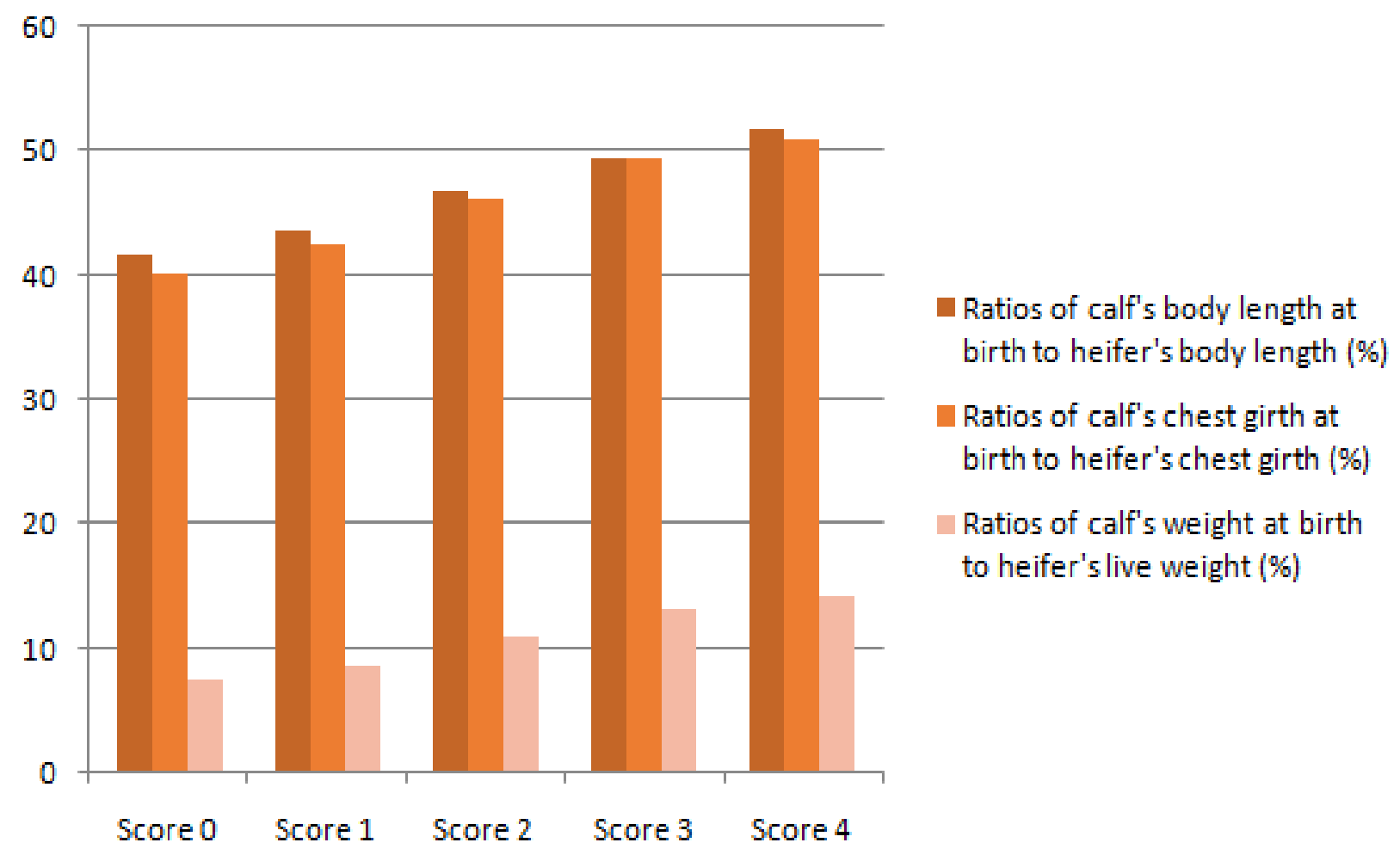

Gambar 4a. Rasio sifat-sifat phenotype anak terhadap sifat-sifat yang sama dari induk remaja bersama skor-skor kesulitan partus $(0=$ partus normal sampai $4=$ partus lebih sulit)
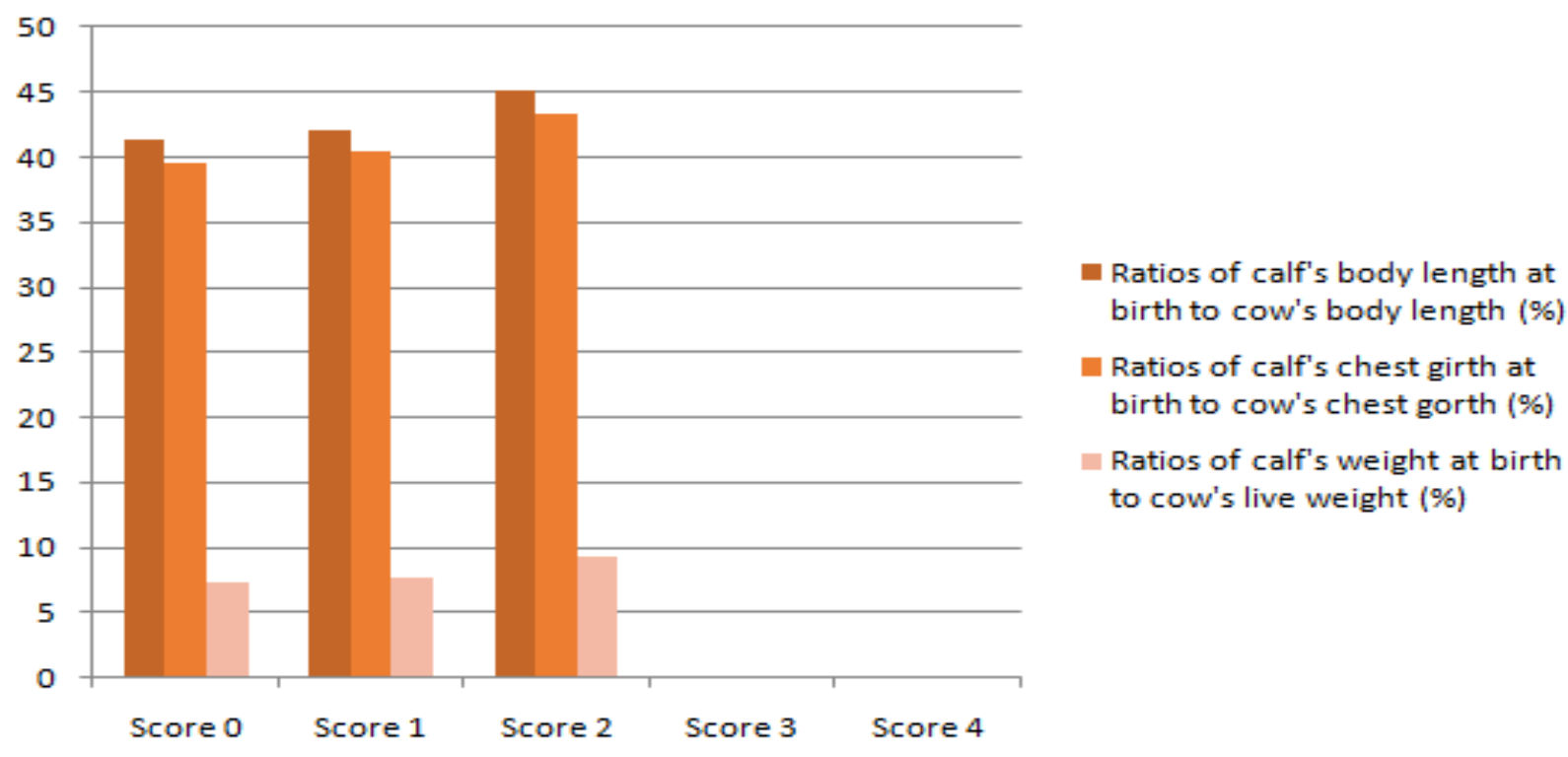

Gambar 4b. Rasio sifat-sifat phenotype anak terhadap sifat-sifat yang sama dari induk dewasa bersama skor-skor kesulitan partus $(0=$ partus normal sampai $4=$ partus lebih sulit) tanpa adanya induk dewasa berada dalam skor 3 dan skor 4. 


\section{KESIMPULAN}

Bobot hidup dan dimensi tubuh rendah kelompok induk remaja cenderung mengalami insiden tinggi dalam kesulitan partus dibandingkan sifat-sifat tersebut dari kelompok induk dewasa. Bobot hidup induk dewasa yang lebih tinggi dapat digunakan sebagai bibit pengganti potensial dalam bangsa sapi Bali guna perbaikan performan anak keturunan untuk mencegah insiden kesulitan partus. Catatan bobot hidup tinggi individu ternak dikombinasikan dengan penerapan persilangan antar bangsa ternak sebaiknya dilakukan untuk program pengembangbiakan ternak dalam meningkatkan populasi ternak unggul pada perbaikan pendapatan masyarakat petani peternak di areal pedesaan.

\section{SARAN}

Kesulitan partus pada induk remaja pertama kawin dapat dikurangi melalui strategi: 1) Seleksi induk remaja yang relative berkembang baik pada sifat panjang badan, lingkar dada dan bobot hidup untuk diharapkan pada bobot lahir anak yang baik, dan 2) Penjagaan kondisi badan optimum untuk induk remaja dan induk dewasa selama periode kebuntingan.

\section{UCAPAN TERIMA KASIH}

Dukungan biaya/dana dari Universitas Sam Ratulangi melalui skim program penelitian Riset Terapan Unggulan Universitas (RTUU) sangat dihargai dengan penuh terima kasih.

\section{DAFTAR PUSTAKA}

Atashi, H., A.R. Abdolmohammadi, A. Asaadi, A. Akhlaghi, M. Dadpasand dan Y. Jafari Ahangari. 2012a. Using an incomplete gamma function to quantify the effect of dystocia on the lactation performance of Holstein dairy cows in Iran. Journal of Dairy Science 95: 2718-2722.

Atashi, H., A.R. Abdolmohammadi, M. Dadpasand dan A. Asaadi. 2012b. Prevalence, risk factors and consequent effect of dystocia in Holstein dairy cows in Iran. AsianAustralian Journal of Animal Science 25(4): 447-451.

Barrier, A.C. dan M.J. Haskell. 2011. Calving difficulty in dairy cows has a longer effect on saleable milk yield than on estimated milk production. Journal of Dairy Science 94: 1804-1812.

Berry, D.P., J.M. Lee, K.A. McDonald dan J.R. Roche. 2007. Body condition score and body weight effects on dystocia and stillbirths and consequent effects on postcalving performance. Journal of Dairy Science 90 : 4201-4211.

Boujenane, I. 2017. Non-genetic factors affecting dystocia and its effects on 
milk production of Holstein dairy cows in Morocco. Livestock Research for Rural Development 29 (8): \# 149.

Bugiwati, S.R.A. 2007. Body dimension growth of calf bull in Bone and Baru District, South Sulawesi.Journal Sains and Tekno 7:103-108.

Byrkit, D.R. 1987. Statistics Today: A Comprehensive Introduction. The Benyamin/ Cummings Publishing Company, Inc. Menlo Park, California.

Departemen Pertanian, RI. 1983. Pedoman Tehnis Peternakan. Direktorat Bina Produksi Peternakan, Direktoral Jenderal Peternakan, DEPTAN RI.

Dinas Kehewanan Kabupaten Minahasa. 2010. Laporan Tahunan Peternakan Kabupaten Minahasa. Tondano, Sulawesi Utara.

Frandson, R.D. 1992. Anatomi dan Fisiologi Ternak. Universitas Gadjah Mada Press. Yogyakarta

Fiedlerova, M., D. Rehak, M. Vacek, J. Volek, J. Fiedler, P. Simecek, O. Masata dan F. Jilek. 2008. Analysis of non-genetic factors affecting calving difficulty in the Czech Holstein population. Czech Journal of Animal Science 53(7):284-291

Gurcan, I.S., D. Ozen, A. Yamaç dan O. Gullu. 2014. Investigation of effect of year and season factors on calving difficulty, using poisson regression model in Simmental $x$ South Anatolian red crossbred cattle. Ankara Üniv Vet Fak Derg 61: 55-58.

Hafez, B dan Hafez, E.S.E. 2000. Reproduction in Farm Animal. $7^{\text {th }}$ Ed. Philadelphia: Lippincott Williams and Wilkins.
Haskell, M.J. dan A.C. Barrier. 2014. Dystocia in cattle: effects on the calf. Veterinary Ireland Journal 4(9) :480482.

Hendrik, J.M. dan U. Paputungan. 2016. Evaluation of parental dam birth weights associated with live weights and calving ease of female progeny of Indonesian-grade cattle. Livestock Research for Rural Development 28 (6): 100.

Imron, A. 2008. Biologi Reproduksi. Universitas Brawijaya. Malang.

Jackson, P.G.G. 2004. Handbook of Veterinary Obstetric. Elsevier Saunders Company.

Johanson, J.M. dan P.J. Berger. 2003. Birth weight as a predictor of calving ease and perinatal mortality in Holstein cattle. Journal of Dairy Science 86: 3745-3755

Johanson, J. M., P.J. Berger, S. Tsuruta dan I. Misztal. 2011. A bayesian threshold-linear model evaluation of perinatal mortality, dystocia, birth weight and gestation in a Holstein herd. Journal of Dairy Science 94: 450-460.

Lelana, N.E., S. Sutarno dan N. Etikawati. 2003. Identifikasi polimorfisme pada fragmen ND-5 DNA mitokondria sapi Benggala dan Madura dengan teknik PCR-RLFP. Biodiversitas 4 (1): 1-6.

Lombard, J.E., S. Tomlinson, F.B. Garry, L.P. Garber dan H.L. Hirst. 2003. Effects of dystocia in three Colorado dairies, Proceedings of the $10^{\text {th }}$ International Symposium on Veterinary Epidemiology and Economics, 2003. Available at www.sciquest.org.nz 
Manan, D. 2002. Ilmu Kebidanan Pada Ternak. Proyek Peningkatan Penelitian Perguruan Tinggi. Dirjen. Dikti. Departemen Pendidikan Nasional.

McGuirk, B.J., R. Forsyth dan H. Dobson. 2007. Economic Cost of Difficult Calvings in the United Kingdom Dairy Herd. Veterinary Record 161: 685-687

Mee, J.F. 2004. Managing the dairy cow at calving time. Veterinary Clinics of North America Food Animal Practice 20: $521-546$

Mee, J.F. 2008. Prevalence and risk factors for dystocia in dairy cattle: A review. The Veterinary Journal 176: 93-101.

Meredith, M.J. 2000. Animal Breeding and Infertility. Blackwell Science Ltd. Australia.

Olson, K.M., B.G. Cassell, A.J. McAllister dan S.P. Washburn. 2009. Dystocia, stillbirth, gestation length, and birth weight in Holstein, Jersey, and reciprocal crosses from a planned experiment. Journal of Dairy Science 92: 6167-6175.

Ozkaya, S. dan Y. Bozkurt. 2009. The relationships of parameters of body measures and body weight by using digital image analysis in pre-slaughter cattle. Arch Tiers, Dummerstorf 51 (2):120-128.

Paputungan, U., M. Makarechian and M.F. Liu. 2000. Effects of sire birth weight on calving difficulty and maternal performance of their female progeny. Asian-Australasian Journal of Animal Science 13(13):729-732.

Paputungan, U., M.J. Hendrik, A. Lomboan dan K. Maaruf. 2015. Study of Indonesian Ongole-crossbred cattle production and income over feed cost for supplements of agricultural waste product formulated in the urea palm sugar block. Livestock Research for Rural Development 28 (08): \# 167.

Paputungan, U., L. Hakim, G. Ciptadi dan H.F.N. Lapian. 2016. Evaluation of growth hormone genotypes associated with live weight of progeny generation $\left(\mathrm{G}_{1}\right)$ derived from parental generation $\left(\mathrm{G}_{0}\right)$ of Indonesian grade cattle. Livestock Research for Rural Development 28 (02): \# 28.

Paputungan, U. dan J.H. Manopo. 2009. Produktifitas Sapi PO Yang Diberi Pakan Tambahan Urea Gula Merah Blok. Laporan Penelitian Proyek Hibah Bersaing, Lemlit-Unsrat.

Partodihardjo, S. 1980. Ilmu Reproduksi Hewan. Fakultas Kedokteran Hewan, IPB, Bogor.

Preston, T.R. dan R.A. Leng. 2009. Matching Livestock Systems to Available Resources in the Tropics and Subtropics. Penambul Books Australia.Web version http:// www. utafoundation. org/P\&L/ preston \& leng.htm.

Ratnawati, D., W.C. Pratiwi, L. Affandhy. 2007. Petunjuk Teknis Penanganan Gangguan Reproduksi Pada Sapi Potong. Pusat Penelitian dan Pengembangan Peternakan, Pasuruan.

Sutarno, A., J. Junaidi dan B. Tappa. 2005. Polimorfisme MspI pada lokus 2 gen hormon pertumbuhan sapi PO dan pengaruhnya terhadap capaian berat badan harian. Biodiversitas, Vol. 6, No. 2:77-81.

Toelihere, M.R. 2003. Increasing the success rate and adoption of artificial 
insemination for genetic improvement of Bali cattle. "In ACIAR Proceedings of Bali Cattle Workshop on Strategy to Improve Bali Cattle in Eastern Indonesia", p. 48-53.
Udeh, I., P.O. Akporhuarho dan C.O. Onogbe. 2011. Phenotypic correlations among body measurements and physiological parameters in Muturu and Zebu cattle. Asian Research Publishing Network (ARPN) Journal of Agricultural and Biological Science 6 (No.4):1-4. 